\title{
A Study of the Production and Combustion Characteristics of Pyrolytic Oil from Sewage Sludge Using the Taguchi Method
}

\author{
Guan-Bang Chen ${ }^{1, *}$, Jia-Wen $\mathrm{Li}^{2}$, Hsien-Tsung Lin ${ }^{2}$, Fang-Hsien $\mathrm{Wu}^{2}$ and Yei-Chin Chao ${ }^{2, *}$ \\ 1 Research Center for Energy Technology and Strategy, National Cheng Kung University, Tainan 701, Taiwan \\ 2 Department of Aeronautics and Astronautics, National Cheng Kung University, Tainan 701, Taiwan; \\ z9809143@email.ncku.edu.tw (J.-W.L.); P48021027@mail.ncku.edu.tw (H.-T.L.); \\ z10602031@email.ncku.edu.tw (F.-H.W.) \\ * Correspondence: gbchen@mail.ncku.edu.twmailto (G.-B.C.); ycchao@mail.ncku.edu.tw (Y.-C.C.); \\ Tel.: +886-6-2757575 (ext. 51030) (G.-B.C.); +886-6-2757575 (ext. 63690) (Y.-C.C.)
}

Received: 19 July 2018; Accepted: 24 August 2018; Published: 28 August 2018

\begin{abstract}
Sewage sludge is a common form of municipal solid waste, and can be utilized as a renewable energy source. This study examines the effects of different key operational parameters on sewage sludge pyrolysis process for pyrolytic oil production using the Taguchi method. The digested sewage sludge was provided by the urban wastewater treatment plant of Tainan, Taiwan. The experimental results indicate that the maximum pyrolytic oil yield, $10.19 \%$ (18.4\% on dry ash free (daf) basis) by weight achieved, is obtained under the operation conditions of $450{ }^{\circ} \mathrm{C}$ pyrolytic temperature, residence time of $60 \mathrm{~min}, 10^{\circ} \mathrm{C} / \mathrm{min}$ heating rate, and $700 \mathrm{~mL} / \mathrm{min}$ nitrogen flow rate. According to the experimental results, the order of sensitivity of the parameters that affect the yield of sludge pyrolytic oil is the nitrogen flow rate, pyrolytic temperature, heating rate and residence time. The pyrolysis and oxidation reactions of sludge pyrolytic oil are also investigated using thermogravimetric analysis. The combustion performance parameters, such as the ignition temperature, burnout temperature, flammability index and combustion characteristics index are calculated and compared with those of heavy fuel oil. For the blend of sludge pyrolytic oil with heavy fuel oil, a synergistic effect occurs and the results show that sludge pyrolytic oil significantly enhances the ignition and combustion of heavy fuel oil.
\end{abstract}

Keywords: sewage sludge; pyrolytic oil; Taguchi method; thermogravimetric analysis; synergistic effect

\section{Introduction}

Even now, a large part of the global energy supply still depends on fossil fuels, resulting in rapid depletion of these resources and enormous GHG (greenhouse gas) emissions. In order to mitigate the problems associated with this fossil fuel depletion and climate warming, it is necessary to either improve the efficiency of fossil fuel utilization [1,2], or partially replace the use of such fossil fuels with zero or neutral carbon footprint alternative energy supplies [3,4]. Among the alternative fuels that are now being considered, biomass is widely recognized as a promising, eco-friendly source of renewable energy, which has the advantage of being readily available around the world.

Biomass derives from botanical or biological sources, or from a combination of these. Ordinary sources of biomass include agricultural solid waste, forestry residues, municipal waste, energy crops, and biological waste. Sewage sludge, the major municipal waste from the wastewater treatment plants, is a complicated mixture of undigested organics, inorganic materials, and moisture. The traditional treatment of sewage sludge includes agricultural use, incineration, and landfill. However, these methods have several shortcomings. With regard to agricultural use, sewage sludge 
contains pathogenic bacteria, viruses, and parasitic helminths, which can harm the health of humans, animals, and plants. For incineration, the heating value of dewatered sewage sludge is low. For landfill, sludge contains a certain amount of organic substance, which generates a biogas rich in methane. Moreover, the cost of this approach is also increasing, because it is more and more difficult to find appropriate areas for landfill. In addition, with recent increases in the sewage treatment rate, the volume of sludge has grown rapidly, and thus alternative methods of sludge management are urgently needed. Thermochemical processes, such as pyrolysis or gasification, have been studied and recommended as suitable alternatives [5]. Thermochemical processes can produce energy from the sludge and have little influence on the environment.

For conversion into bio-fuel from biomass, biochemical conversion (BCC) and thermochemical conversion (TCC) are the two general broad approaches. BCC often uses fermentation and biological conversion processes. Direct combustion, gasification, pyrolysis, and liquefaction are generally used for TCC $[6,7]$. The resulting products can be used directly as fuels, or further processed for specialty chemicals $[8,9]$.

Among the various thermochemical conversion processes, thermal pyrolysis has attracted more interest with regard to yielding liquid fuel products from various biomass species, such as woody biomass [10], bagasse [11], straws [12], miscanthus [13], castor meal [14], oil palm fiber [15], fruit waste [16], and municipal solid waste [6,17]. Even for waste oil, pyrolysis approaches offer some advantages over existing methods (transesterification, hydrotreating, gasification, solvent extraction, and membrane technology) in producing useful pyrolysis products for future reuse [18]. Products from pyrolysis processes depend strongly on the heating rate, heating temperature, gas residence time, particle size of biomass, and water content of the biomass. In fact, great work related to the conversion of biomass to liquid fuels was performed during the oil crisis of the 1970s [19], and most studies on sludge liquid fuel production are based on pyrolysis for lignocellulosic materials. In general, in order to increase the yield of bio-oil, the biomass in the fast pyrolysis process is rapidly heated to a high temperature $\left(425-600{ }^{\circ} \mathrm{C}\right)$ and has a short gas residence time $(<3 \mathrm{~s})$ in the absence of oxygen [20].

The review work of sewage sludge pyrolysis by Fonts et al. [21] placed specific emphasis on liquid sewage sludge pyrolytic fuel production, and detailed comparisons of pyrolytic oils between sewage sludge and lignocellulose were also made. Several studies have performed sewage sludge pyrolysis to produce liquid fuel, which is composed of aqueous and organic phase compounds [22-27]. Some papers emphasize the influence of operational conditions and composition on the sludge pyrolysis product, especially the liquid yield. There are few studies related to the maximum yield of sludge pyrolytic oil and its combustion characteristics. Therefore, in this study we examined the influence of different key parameters on sewage sludge pyrolysis process for pyrolytic oil using the Taguchi method. As an example, the method was applied in determining the pyrolysis process parameters of the digested sewage sludge provided by the urban wastewater treatment plant of Tainan, Taiwan. The combustion characteristics of the resulting pyrolytic oil are also investigated by thermogravimetric analysis. The experimental results are also compared with those for heavy fuel oil, since the co-firing of sludge pyrolytic oil with heavy fuel oil is a promising potential alternative for practical applications.

\section{Methodology}

\subsection{Experimental Setup}

The feedstock used for the studies is typical digested sewage sludge from a wastewater treatment plant in Tainan, Taiwan (Figure 1). Even though the sludge is dewatered in the wastewater treatment plant, its water content is still higher than $30 \%$. Therefore, before the pyrolysis experiment, the sewage sludge was preheated to $110^{\circ} \mathrm{C}$ in an oven until the water content of the sewage sludge was lower than $10 \%$ (see Table 1). The drying step is important and can even affect the conversion of a waste into other products with high added value [28]. Figure 2a depicts the experimental thermal pyrolysis 
apparatus. In the experiment, the dried sewage sludge was mixed and ground to pass through a 100-mesh sieve, and $90 \mathrm{~g}$ of sewage sludge were packed in a cylindrical holder made of quartz and put into the furnace. The covers of the cylindrical holder were made of stainless steel with many holes. For pyrolysis, the tubular furnace was first vacuumed, and then flushed with $\mathrm{N}_{2}$ to ambient pressure. The furnace was then heated to the preset temperature and maintained at the temperature for a designated residence time. The residence time here is different from the gas residence time, which represents the residence time for pyrolytic vapor inside the pyrolysis furnace. In addition, the gas residence time is inversely proportional to the nitrogen flow rate. The heated carrier gas can flow into the holder and interact with the sludge. The generated volatile gas was collected and delivered to a condensing system kept at $25^{\circ} \mathrm{C}$ to form a liquid product. Figure $2 \mathrm{~b}$ shows the thermal pyrolysis operating process in a fixed-bed tubular furnace and it must undergo two steps: being heated up from room temperature to the target temperature at a specific heating rate and holding at the targeted temperature for a designated residence time. The production of pyrolytic oil occurs in a certain conditions and is influenced by the combination of four operational parameters: heating rate, target pyrolytic temperature, residence time, and nitrogen flow rate. The Taguchi method will be used to analyze the influence of this parameter combination on the pyrolytic oil production from sewage sludge using a fixed-bed tubular furnace. After the experiment, the condensing bottle was held for $24 \mathrm{~h}$, and the pyrolytic oil was separated from the aqueous matter using a separatory funnel. This pyrolytic oil has a high heating value, and was the target product in the study. As to the aqueous product, it could be used as a source for fertilizers or chemicals due to the nitrogen-containing compounds [29], or as a source of triacetonamine [30].

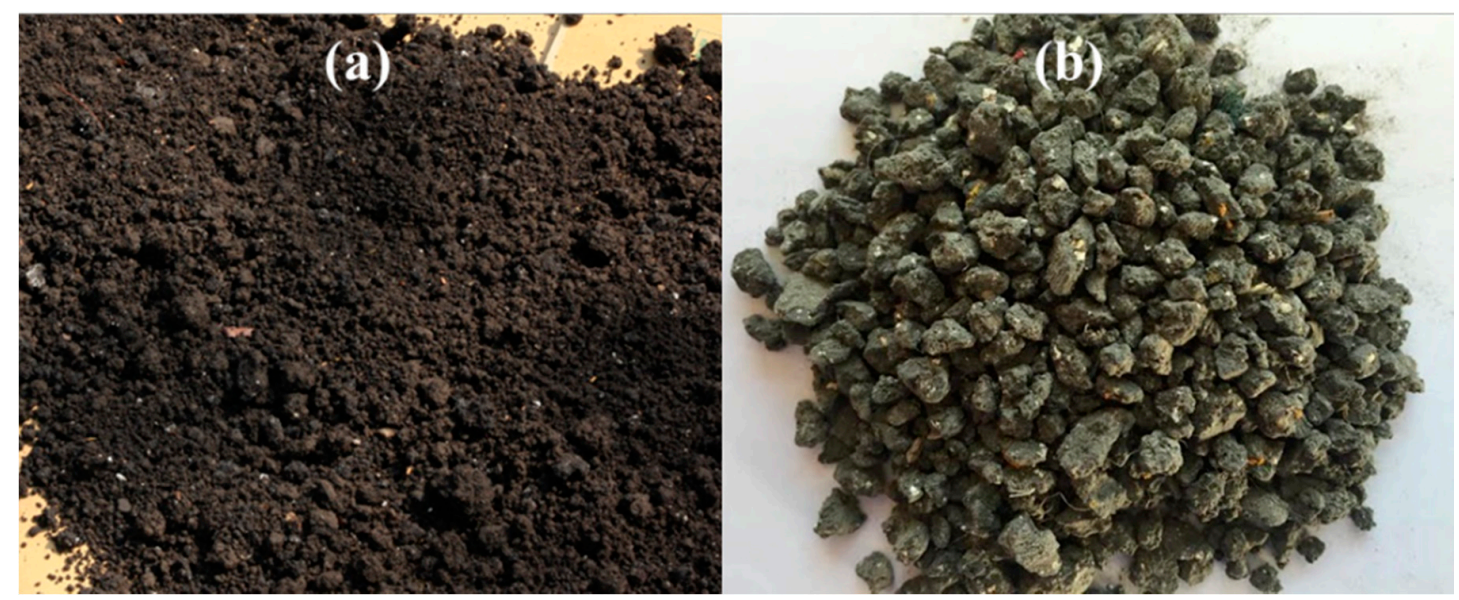

Figure 1. Photograph of sewage sludge, (a) sludge from the wastewater treatment plant and (b) sludge after preheating.

Table 1. Proximate analysis of sewage sludge.

\begin{tabular}{ccc}
\hline Proximate Analysis & Sewage Sludge & Sewage Sludge [21] \\
\hline Moisture (wt \%) & 6.94 & $1.5-7.1$ \\
Volatiles (wt \%) & 45.45 & $38.3-66.8$ \\
Ash (wt \%) & 37.67 & $22.6-52.0$ \\
Fixed carbon $(w \mathrm{t} \%)$ & 9.94 & $0.8-19.7$ \\
\hline
\end{tabular}


(a)

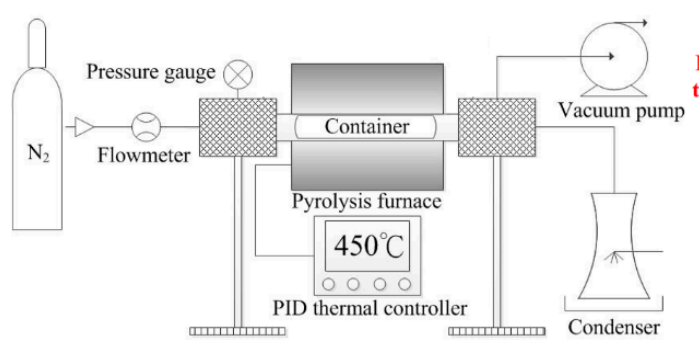

(b)

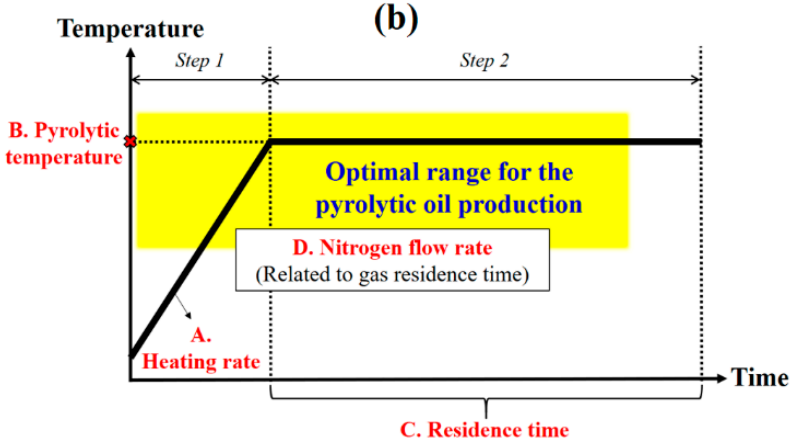

Figure 2. Schematic diagram of (a) experimental setup and (b) operating process for thermal pyrolysis.

Simultaneous thermogravimetric analysis (TGA) and differential scanning calorimetry (DSC) measurement were performed using the thermal analyzer (PerkinElmer, Waltham, MA, USA: STA 8000). The temperature range was $30-1200{ }^{\circ} \mathrm{C}$, with a heating rate of $10^{\circ} \mathrm{C} / \mathrm{min}$. A $145-\mu \mathrm{L}$ alumina crucible was used to hold the testing sample, and the flow rate of air or nitrogen environmental gas was $50 \mathrm{~mL} / \mathrm{min}$.

A portable $\mathrm{pH}$ meter (ROCKER, New Taipei City, Taiwan: EC-210) was used to measure the $\mathrm{pH}$ value of sludge pyrolytic oil, with an accuracy of about $0.01 \pm 1$ digit. The $\mathrm{pH}$ value of sludge pyrolytic oil can be measured directly because of the low water content. In addition, a bomb calorimeter (Parr Instrument, Moline, IL, USA: Model 6200) was used to measure the heating values of different samples, while an elemental analyzer (Elementar, Langenselbold, Hesse, Germany: vario EL III) was used to analyze the $\mathrm{C}, \mathrm{H}, \mathrm{O}, \mathrm{N}$ and $\mathrm{S}$ composition of the sewage sludge, pyrolytic sludge oil and heavy fuel oil. The chemical compounds contained in the sludge pyrolytic oil were analyzed by Agilent 7890A-GC and Agilent 5975C-MSD (Agilent Technologies, Santa Clara, CA, USA).

\subsection{Taguchi Method}

The Taguchi method was used to find the maximum yield of sludge pyrolytic oil from the pyrolysis experiments. The feature of the Taguchi method uses an orthogonal array experimental design with a simple analysis of variance. In Taguchi method, the variables are assigned to each column, called orthogonal arrays for the design of experiments [31], of a matrix related to experimental parameters and experiment levels. In general, the Taguchi method is not aimed at finding the optimal conditions as a full factorial method, but it can analyze the best trend with fewer experimental data, and thus is commonly applied to optimize industrial processes.

Taguchi method was previously applied to analyze caster meal pyrolysis by Chen et al. and this group [14]. The Taguchi method uses the $S / N$ ratio, the signal to noise ratio, to measure the quality characteristics deviating from the desired value [32]. Different strategic categories of nominal-the best (NTB), smaller the better (STB), and larger the better (LB) - are used to describe the $S / N$ ratio characteristics [33]. In this study, for example, to obtain the maximum yield of pyrolytic oil, the "larger the better" characteristic must be adopted. The expression of $S / N$ ratio is shown as follows:

$$
S / N_{L B}=-10 \log \left(\frac{1}{N} \sum_{i=1}^{N} \frac{1}{y_{i}^{2}}\right)=-10 \log \left[\frac{1}{\overline{y^{2}}}\left(1+\frac{3 s^{2}}{\overline{y^{2}}}\right)\right],
$$

where $N$ is the test number, $y_{i}$ is the value of the pyrolytic oil yield in the $i$ th test, and $\bar{y}$ is the average yield of pyrolytic oil. The procedure for the experimental design with the Taguchi method can be found in previous work [14]. 


\subsection{Characteristic Combustion Parameters}

Several characteristic combustion parameters can be deduced from a TG-DTG curve to assess the combustion properties of fuels. This study will make use of the ignition temperature $\left(T_{i}\right)$, burnout temperature $\left(T_{e}\right)$, combustion characteristics index $(S)$, and flammability index $(C)$ to evaluate the combustion characteristics of sludge pyrolysis oil mixed with different percentages of heavy fuel oil. The weight loss curve is used to define the ignition temperature. There are many studies concerning the definition of the ignition temperature using TG-DTG curves [34-36], and the method proposed by Tognotti et al. [34] is widely used to predict the ignition temperature for different fuels. In this, the weight loss curve of fuel in the air atmosphere is overlapped with that in inert gas atmosphere $\left(\mathrm{N}_{2}\right)$, and the ignition temperature $\left(T_{i}\right)$ corresponds to the first bifurcation point in the TG curves [37]. In addition, the burnout temperature $\left(T_{e}\right)$ is defined as the temperature corresponding to 99\% conversion of the fuel in the TG curve of air atmosphere.

Since the ignition and burnout temperatures show only a single combustion property of the fuel, an integrated index is required for the global combustion performance of fuels. Therefore, the combustion characteristic index $(S)$ and flammability index $(C)$ are also used for benchmarking the combustibility of fuels [38]. The combustion characteristic index $(S)$ was first proposed by Cheng et al. [39]. The larger the combustion characteristics index, the better the combustion characteristics of the fuel. The combustion rate is expressed by the Arrhenius Law, as follows:

$$
d W / d \tau=\mathrm{A} \exp (-\mathrm{E} / \mathrm{RT})
$$

where $d W / d \tau$ is the combustion rate, $\mathrm{A}$ is a pre-exponential factor, $\mathrm{E}$ is the activation energy, and $\mathrm{T}$ is the absolute temperature.

Take the differential of Equation (2) with temperature and rearrange it as follows:

$$
\frac{R}{E} \times \frac{d}{d T}\left(\frac{d W}{d \tau}\right)=\frac{d W}{d \tau} \times \frac{1}{\mathrm{~T}^{2}}
$$

At ignition temperature $T_{i}$, Equation (3) is multiplied by $\frac{(d W / d \tau)_{\max }(d W / d \tau)_{\text {mean }}}{(d W / d \tau)_{T=T_{i}} T_{e}}$ :

$$
\frac{R}{E} \times \frac{d}{d T}\left(\frac{d W}{d \tau}\right)_{T=T i} \frac{(d W / d \tau)_{\max }}{(d W / d \tau)_{T=T i}} \times \frac{(d W / d \tau)_{\text {mean }}}{T_{e}}=\frac{(d W / d \tau)_{\max } \times(d W / d \tau)_{\text {mean }}}{T_{i}{ }^{2} \times T_{e}}
$$

where $(d W / d \tau)_{\max }$ is the maximum combustion rate, which can be obtained from the peak of DTG curve. $(d W / d \tau)_{\text {mean }}$ is the mean combustion rate, which can be obtained from the mean of DTG curve. The first term of Equation (4) on the left-hand side represents the reaction strength of fuel combustion, which is related to the activation energy. The second term stands for the change rate of fuel combustion rate at the ignition temperature and the third term refers to the ratio of maximum combustion rate to the combustion rate at the ignition temperature. These two terms are related to the ignition temperature. The last term is the ratio of mean combustion rate to the burnout temperature; the larger the value, the shorter the burnout time of the fuel.

The right-hand side of Equation (4) is the combustion characteristic index $(S)$ :

$$
S=\frac{(d W / d \tau)_{\max } \times(d W / d \tau)_{\text {mean }}}{T_{i}^{2} \times T_{e}}
$$

The flammability index combines the influence of maximum combustion rate and the ignition temperature. It can reflect the difficulty of fuel combustion and the burning out speed. The fuel with a 
large flammability index will have better combustion stability and the flammability index $(C)$ of the sample can be expressed as follows:

$$
C=(d W / d \tau)_{\max } / T_{i}^{2}
$$

\section{Results and Discussion}

\subsection{Thermogravimetric Analysis of Sewage Sludge}

Table 1 shows the approximate analysis of the sewage sludge used in this study, and it is composed of $6.94 \mathrm{wt} \%$ moisture, $45.45 \mathrm{wt} \%$ volatiles, $9.94 \mathrm{wt} \%$ fixed carbon, and $37.67 \mathrm{wt} \%$ ash. This composition is well within the range of the different kinds of sewage sludge analyzed by Fonts et al. [21].

Figure 3 shows the TGA thermograph of sewage sludge. The heating rate is $10{ }^{\circ} \mathrm{C} / \mathrm{min}$ and the nitrogen flow rate is $50 \mathrm{~mL} / \mathrm{min}$. The purple curve shows thermogravimetry (TG), the blue curve shows differential of thermogravimetry (DTG), the red curve shows differential scanning calorimetry (DSC), while the green curve represents TG in air atmosphere. The mass loss of sewage sludge increases along with the temperature, and the major reactions occur between $120^{\circ} \mathrm{C}$ and $500{ }^{\circ} \mathrm{C}$.

For the purple TG curve in Figure 3, there are three stages of weight loss. The first stage has a weight loss of $9.33 \%$ in the temperature range of $30-200{ }^{\circ} \mathrm{C}$, due to the removal of the water and organics with low boiling points. In the second stage, there are two distinct peaks at the temperatures of $273{ }^{\circ} \mathrm{C}$ and $323^{\circ} \mathrm{C}$ in the DTG curve. About $33.57 \%$ of the original sewage sludge is lost, and this is mainly from the decomposition of aliphatic compound protein and carbohydrates contained in the sewage sludge [40-43]. In the third stage, the weight loss tends to be mild when the temperature exceeds $500{ }^{\circ} \mathrm{C}$, which might be from the decomposition of residual organic matter and the inorganic materials, such as calcium carbonate [44]. Finally, the residue is about $46.79 \%$ of the original weight of the sewage sludge when the temperature reaches $1000^{\circ} \mathrm{C}$.

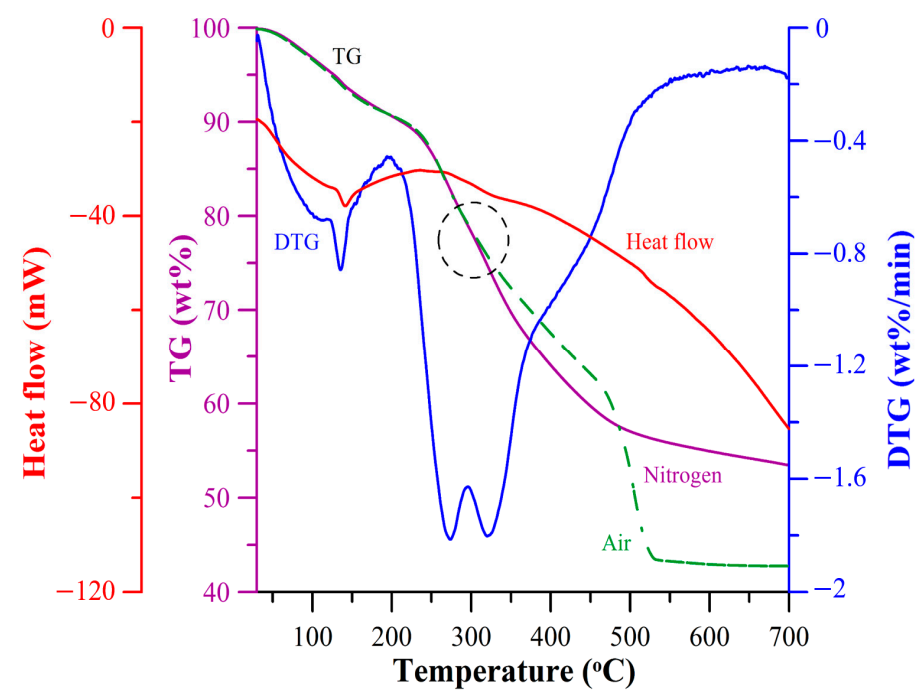

Figure 3. Thermogravimetric analysis results for sewage sludge at a heating rate of $10{ }^{\circ} \mathrm{C} / \mathrm{min}$ and nitrogen flow rate of $50 \mathrm{~mL} / \mathrm{min}$.

\subsection{Pyrolytic Parameters for Sewage Sludge}

\subsubsection{The Influence of Nitrogen Flow Rate on the Pyrolytic Oil Yield}

Inert carrying gases such as nitrogen and carbon dioxide are often used in the pyrolysis process. Inert gas can keep the reactor in an oxygen-free state, and causes the volatiles to move quickly away 
from the system and thus avoid condensing again. Pütün et al. investigated the effects of the sweeping gas flow rate $\left(\mathrm{N}_{2}\right)$ on pyrolysis products, and found that increasing the sweeping gas will reduce the gas residence time and prevent the pyrolytic products from the secondary thermal decomposition, thus maximizing the liquid yield [45].

The influence of the $\mathrm{N}_{2}$ flow rate on the sludge pyrolytic oil was also investigated in this study, as shown in Figure 4. The conditions were fixed as a pyrolytic temperature of $500{ }^{\circ} \mathrm{C}$, heating rate of $20^{\circ} \mathrm{C} / \mathrm{min}$ and residence time of $60 \mathrm{~min}$. The pyrolytic oil yield increases with the $\mathrm{N}_{2}$ flow rate in the range of $300-700 \mathrm{~mL} / \mathrm{min}$. However, it then decreases again after the $\mathrm{N}_{2}$ flow rate surpasses $700 \mathrm{~mL} / \mathrm{min}$. Higher liquid yield is usually obtained in a certain range of gas residence time. According to the volume of the quartz holder in this study, the filled volume of $90 \mathrm{~g}$ sludge and the nitrogen flow rate of $700 \mathrm{~mL} / \mathrm{min}$, the gas residence time is between $2.5 \mathrm{~s}$ and $3 \mathrm{~s}$. It is under the range preferred for fast pyrolysis to obtain more oil product [20]. When the nitrogen flow rate is less than $700 \mathrm{~mL} / \mathrm{min}$, the gas residence time is increased and this gas residence time may cause condensable gases secondary decomposition, which is not conducive to oil product. Nevertheless, the variation in the nitrogen flow rate would also vary the degree of dilution of the pyrolysis vapors. When the dilution of the vapors increases, the vapor pressure decreases, making it more difficult to reach saturation pressure. This affects the condensation and thus the liquid yield. It is speculated this reason make sludge pyrolytic oil decrease after the nitrogen flow rate exceeds $700 \mathrm{~mL} / \mathrm{min}$. Therefore, the nitrogen flow rate was chosen as 300, 500, 700 and $900 \mathrm{~mL} / \mathrm{min}$ in the following work.

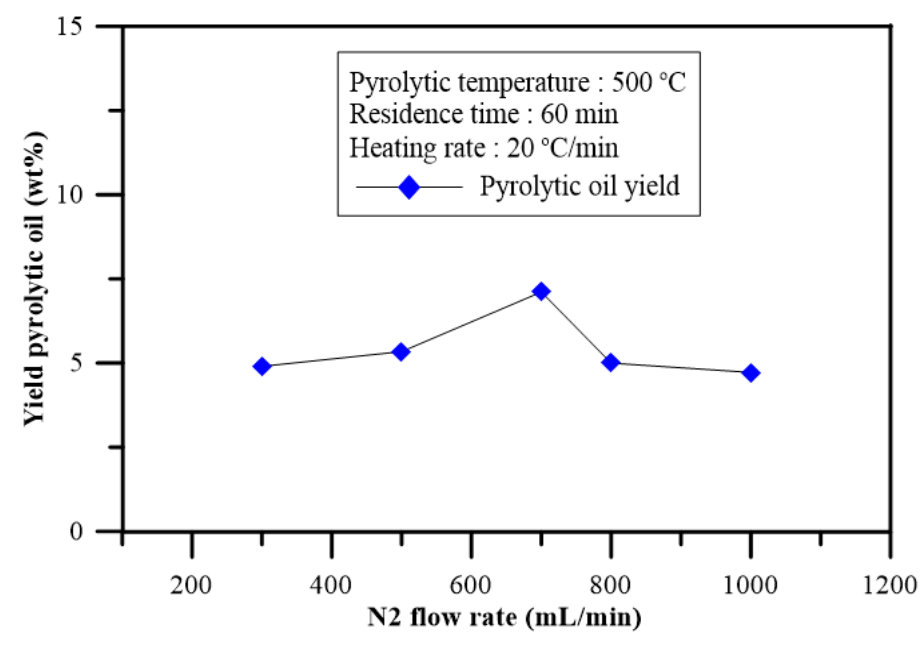

Figure 4. The effect of nitrogen flow rate on the yield of pyrolytic oil.

\subsubsection{The Optimal Conditions for Sludge Pyrolysis}

The optimal pyrolysis conditions for the maximum yield of sludge pyrolytic oil are investigated in the fixed-bed reactor using the Taguchi method. Table 2 gives the pyrolysis parameters and their levels. Four pyrolysis parameters are the heating rate, pyrolysis temperature, residence time, and nitrogen flow rate. These parameters are assumed to be independent and each parameter has four levels. According to the number of parameters and their levels, the $\mathrm{L}_{16}\left(4^{5}\right)$ orthogonal array will be selected. Table 3 shows the experimental layout using an $\mathrm{L}_{16}\left(4^{5}\right)$ orthogonal array and the original 256 experimental conditions for the full factorial method are thus diminished significantly to only 16 . Table 4 reveals the mass balances of all 16 experimental conditions, including aqueous, oil, and solid yields. Gas yield was obtained by calculation since it was not collected. It shows that sewage sludge char accounts for $50-60 \%$ of total product, and the liquid yield is in the range of $18-27 \%$. To assure the reliability of the results, each experiment was performed three times to take the average. 
Table 2. Pyrolysis control factors and their levels.

\begin{tabular}{ccccc}
\hline & Level 1 & Level 2 & Level 3 & Level 4 \\
\hline Heating rate $\left({ }^{\circ} \mathrm{C} / \mathrm{min}\right)$ & 10 & 20 & 30 & 40 \\
Temperature $\left({ }^{\circ} \mathrm{C}\right)$ & 450 & 500 & 550 & 600 \\
Residence time $(\mathrm{min})$ & 30 & 60 & 90 & 120 \\
$\mathrm{~N}_{2}$ flow rate $(\mathrm{mL} / \mathrm{min})$ & 300 & 500 & 700 & 900 \\
\hline
\end{tabular}

Table 3. Experimental layout using an $\mathrm{L}_{16}\left(4^{5}\right)$ orthogonal array.

\begin{tabular}{cccccc}
\hline $\begin{array}{c}\text { Experiment } \\
\text { No. }\end{array}$ & $\begin{array}{c}\text { Heating Rate } \\
\left({ }^{\circ} \mathbf{C} \text { /min) }\right.\end{array}$ & $\begin{array}{c}\text { Temperature } \\
\left({ }^{\circ} \mathbf{C}\right)\end{array}$ & $\begin{array}{c}\text { Residence } \\
\text { Time }(\mathbf{m i n})\end{array}$ & $\begin{array}{c}\mathbf{N}_{\mathbf{2}} \text { Flow Rate } \\
(\mathbf{m L} / \mathbf{m i n})\end{array}$ & $\begin{array}{c}\text { Cooling } \\
\text { Temperature }\left({ }^{\circ} \mathbf{C}\right)\end{array}$ \\
\hline 1 & 10 & 450 & 30 & 300 & 25 \\
2 & 10 & 500 & 60 & 500 & 25 \\
3 & 10 & 550 & 90 & 700 & 25 \\
4 & 10 & 600 & 120 & 900 & 25 \\
5 & 20 & 450 & 60 & 700 & 25 \\
6 & 20 & 500 & 30 & 900 & 25 \\
7 & 20 & 550 & 120 & 300 & 25 \\
8 & 20 & 600 & 90 & 500 & 25 \\
9 & 30 & 450 & 90 & 900 & 25 \\
10 & 30 & 500 & 120 & 700 & 25 \\
11 & 30 & 550 & 30 & 500 & 25 \\
12 & 30 & 600 & 60 & 300 & 25 \\
13 & 40 & 450 & 120 & 500 & 25 \\
14 & 40 & 500 & 90 & 300 & 25 \\
15 & 40 & 550 & 60 & 900 & 700 \\
16 & 40 & 600 & 30 & & \\
\hline
\end{tabular}

Table 4. The mass balances of all 16 experimental conditions.

\begin{tabular}{ccccc}
\hline Experiment No. & Aqueous (wt \%) & Oil (wt \%) & Solid (wt \%) & Gas (by diff.) (wt \%) \\
\hline 1 & 11.42 & 8.71 & 57.02 & 22.85 \\
2 & 12.67 & 8.88 & 55.09 & 23.36 \\
3 & 15.06 & 9.87 & 54.48 & 20.60 \\
4 & 13.42 & 7.29 & 52.18 & 27.11 \\
5 & 14.93 & 8.76 & 54.92 & 21.40 \\
6 & 14.09 & 7.91 & 53.37 & 24.63 \\
7 & 14.31 & 8.62 & 52.45 & 24.62 \\
8 & 9.44 & 9.22 & 54.10 & 27.24 \\
9 & 13.41 & 8.31 & 55.80 & 22.49 \\
10 & 12.12 & 9.32 & 54.56 & 24.00 \\
11 & 12.93 & 6.59 & 53.10 & 27.38 \\
12 & 13.76 & 7.58 & 52.91 & 25.75 \\
13 & 14.70 & 9.20 & 54.43 & 21.66 \\
14 & 13.11 & 5.43 & 54.30 & 27.17 \\
15 & 18.41 & 9.22 & 53.33 & 19.03 \\
16 & 15.67 & 7.88 & 51.82 & 24.63 \\
\hline
\end{tabular}

After obtaining the experimental yield of sludge pyrolytic oil, the corresponding $S / N$ ratio can be calculated using Equation (1). Since the experimental design is orthogonal, the effect of each pyrolysis parameter at different levels can be separated out. The mean $S / N$ ratio for the 16 experimental conditions is computed and the mean $S / N$ ratio for each level of the other pyrolysis parameters can then be calculated. The $S / N$ response for the mean $S / N$ ratio of the pyrolysis parameters at each level are shown in Table 5 and it is used to determine the maximum yield of sludge pyrolytic oil. 
Table 5. $S / N$ response table for sludge pyrolytic oil.

\begin{tabular}{lccccc}
\hline & L1 & L2 & L3 & L4 & Max-Min \\
\hline (A) Heating rate & -21.27 & -21.29 & -22.06 & -22.20 & 0.929 \\
(B) Temperature & -21.17 & -22.25 & -21.43 & -21.98 & 1.074 \\
(C) Residence time & -22.23 & -21.32 & -21.93 & -21.34 & 0.910 \\
(D) $\mathrm{N}_{2}$ flow rate & -22.55 & -21.52 & -20.99 & -21.77 & 1.564 \\
\hline
\end{tabular}

Based on the experimental results and the calculated $S / N$ ratio, the optimal operation conditions are determined as shown in Figure 5. In Figure 5, these four pyrolysis parameters are labelled as " $\mathrm{A}$ " for heating rate, " $B$ " for pyrolytic temperature, " $C$ " for residence time, and " $D$ " for nitrogen flow rate. Although the results for pyrolytic temperature and residence time are zigzag, several studies concerning the Taguchi method also show the same phenomenon for $S / N$ ratios [46-48]. It can be deduced from Figure 5 that the optimal pyrolysis conditions are A1, B1, C2 and D3, which represent a heating rate of $10^{\circ} \mathrm{C} / \mathrm{min}$, pyrolytic temperature of $450{ }^{\circ} \mathrm{C}$, residence time of $60 \mathrm{~min}$, and nitrogen flow rate of $700 \mathrm{~mL} / \mathrm{min}$. It should be mentioned that fast pyrolysis, which represents a pyrolysis reaction carried out at high heating rates, moderate temperatures and short gas residence times, is usually used to obtain high yield of pyrolysis oil. There are three main kinds of technologies for fast pyrolysis: ablative pyrolysis, fluidized bed pyrolysis, and vacuum pyrolysis. However, in the study, a tubular furnace, a type of fixed-bed reactor was used. The results show that oil yield was affected by the combination of four operational parameters. The heating rate is not the dominant parameter due that it was restricted by the pyrolytic temperature. Among these parameters, the nitrogen flow rate has the most obvious effect, which is followed by the pyrolytic temperature and the residence time has the least effect. The nitrogen flow rate (inversely proportional to the gas residence time) has a more significant effect on the oil yield than heating rate.

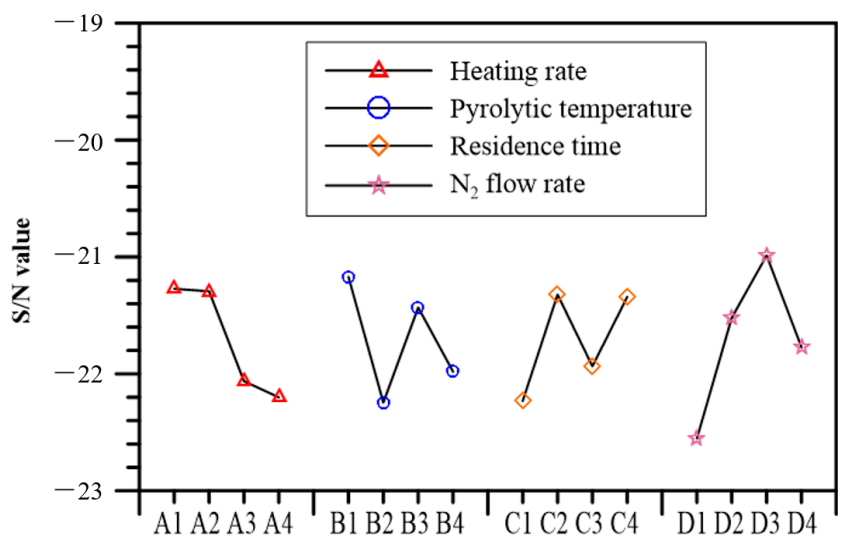

Figure 5. $S / N$ response for sludge pyrolytic oil.

\subsubsection{Confirmation Experiment}

In the Taguchi method, the confirmation experiment is the last step and the aim of this is to validate the yield of sludge pyrolytic oil. After obtaining the optimum conditions and predicting the response under these conditions, a new experiment was performed with the optimum levels of these pyrolysis parameters. The theoretical optimal $S / N$ ratio can be estimated as:

$$
S / N_{\mathrm{opt}}=S / N_{\mathrm{AV}}+\left(\mathrm{A} 1-S / N_{\mathrm{AV}}\right)+\left(\mathrm{B} 1-S / N_{\mathrm{AV}}\right)+\left(\mathrm{C} 2-S / N_{\mathrm{AV}}\right)+\left(\mathrm{D} 3-S / N_{\mathrm{AV}}\right)=-19.63,
$$

where $S / N_{\mathrm{AV}}$ is the total mean of the $S / N$ ratio and $S / N_{\text {opt }}$ is the $S / N$ ratio at the optimal level. 
From the experimental results of the standard $\mathrm{L}_{16}\left(4^{5}\right)$ orthogonal array, the theoretical optimization $S / N$ value is -19.63 , and it can be deduced that the theoretical maximum pyrolytic oil yield is $0.1044 \mathrm{~g} / \mathrm{g}$ sewage sludge ( $18.85 \%$ on dry ash free (daf) basis). The real yield of the confirmation experiment is $0.1019 \mathrm{~g} / \mathrm{g}$-sewage sludge ( $18.4 \%$ on dry ash free (daf) basis). The difference is only $0.0025 \mathrm{~g} / \mathrm{g}$ sewage sludge, and thus real experimental result is very close to the theoretical value. In addition, under the optimal conditions, the solid product is about $54.83 \%$, aqueous product is about $15 \%$ and by mass balance, the gas product is $19.98 \%$. Although the solid product is not suitable to be used as fuel due to high content of inorganic matter (ash), it can be used to produce adsorbents for disposing of pollutants such as $\mathrm{H}_{2} \mathrm{~S}$ and $\mathrm{NO}_{x}$ [21]. The aqueous product could be used for the production of fertilizer since it has high content of nitrogen-containing compounds. As to the gas product, it could be recycled and used for the drying of feedstock.

\subsection{Elemental Analysis and Heating Values of the Different Fuels}

Table 6 shows the elemental analysis and heating value for the sewage sludge, sludge pyrolytic oil and heavy fuel oil on the wet basis. The sludge pyrolytic oil is obtained using the optimal conditions from the Taguchi method. The results show that the dried sewage sludge contained $1.28 \%$ sulfur and the sludge pyrolytic oil contained $1.25 \%$ sulfur. Compared to the sulfur content of heavy oil, it can be seen that when using sludge pyrolytic oil as fuel more care must be taken with regard to the $\mathrm{SO}_{\mathrm{X}}$ emissions. However, since the combustion of pure sludge pyrolytic oil appears to be impractical because of the yield, it is more feasible to co-combust this and other fuels, such as heavy fuel oil. In this case, the sulfur content would drop significantly and thus decrease the sulfur oxide emissions. As to the high nitrogen content in the sludge pyrolytic oil, it is usually related to fuel $\mathrm{NO}_{\mathbf{x}}$ during the combustion process. Therefore, the blending ratio of sludge pyrolytic oil and heavy fuel oil should be also well selected to have less $\mathrm{SO}_{x}$ and $\mathrm{NO}_{x}$ emissions. Sludge pyrolytic oil also has a higher oxygen content than heavy fuel oil. A high oxygen content directly affects the energy density, and the resulting heating value is usually lower than that of heavy fuel oil. Although the heating value of sludge pyrolytic oil is only about $2 / 3$ that of heavy fuel oil $(28.66 \mathrm{MJ} / \mathrm{kg}$ vs. $44.87 \mathrm{MJ} / \mathrm{kg})$, it is still significantly higher than the common bio-oil from lignocellulose. In addition, it does not have the corrosive character that is often seen in other pyrolysis liquids obtained from lignocellulosic biomass, as the $\mathrm{pH}$ value of sludge pyrolytic oil is between 8.86 and 9.67 in this study. Accordingly, these advantageous properties make sludge pyrolytic oil favorable as fuel for the co-combustion with other fossil fuels, like heavy fuel oil. In addition, sludge pyrolytic oil contains a high nitrogen and sulfur content, primarily due to the decomposition of protein contained within the dried sewage sludge [21].

Table 6. Elemental analysis and heating values of different fuels.

\begin{tabular}{ccccccc}
\hline Samples & $\mathbf{N} \%$ & $\mathbf{C} \%$ & $\mathbf{H} \%$ & $\mathbf{O} \%$ & $\mathbf{S} \%$ & HHV(MJ/kg) \\
\hline Sewage sludge & 4.14 & 22.62 & 4.93 & 35.29 & 1.28 & 10.18 \\
Sludge pyrolytic oil & 5.92 & 58.44 & 9.08 & 18.98 & 1.25 & 28.66 \\
Heavy fuel oil & 0.46 & 86.7 & 11.81 & 0.26 & 0.28 & 44.87 \\
\hline
\end{tabular}

Table 7 compares the properties of diesel, heavy fuel oil, and sludge pyrolytic oil. The optimal combination conditions obtained from the Taguchi method is used for the yield of sludge pyrolytic oil. The test standards used in this study for different properties are also shown in Table 7 . The density of sludge pyrolytic oil is larger than that of diesel and heavy fuel oils and it is a little higher than the density of water. The viscosity of sludge pyrolytic oil is between that of diesel and heavy fuel oils. The flash point of sludge pyrolytic oil is $80^{\circ} \mathrm{C}$, which makes it safe to use as a fuel. The pour point of sludge pyrolytic oil is lower than that of heavy fuel oil and it still retains mobility at low temperatures. 
Table 7. Properties of different kinds of liquid fuels.

\begin{tabular}{ccccc}
\hline Properties & Diesel & Heavy Fuel Oil & Sludge Oil (Pyrolysis) & Test Method \\
\hline Density $\left(\mathrm{g} / \mathrm{cm}^{3}, @ 15^{\circ} \mathrm{C}\right)$ & 0.8335 & 0.9533 & 1.04 & ASTM D4052 \\
Viscosity $\left(\mathrm{mm}^{2} / \mathrm{s} @ 40^{\circ} \mathrm{C}\right)$ & 3.024 & 130.3 & 64.86 & ASTM D445 \\
Flash Point $\left({ }^{\circ} \mathrm{C}\right)$ & $52-80$ & 110 & 80 & ASTM D93 \\
Pour Point $\left({ }^{\circ} \mathrm{C}\right)$ & -9 & 12 & 6 & ASTM D97 \\
Heating Value $(\mathrm{MJ} / \mathrm{kg})$ & 42.50 & 44.87 & 28.66 & ASTM D240 \\
\hline
\end{tabular}

The bio-oil characterization was carried out using GC/MS spectrometry at the optimal conditions for the maximum yield of the pyrolytic oil. Figure 6 shows the GC/MS mass spectra of sludge pyrolytic oil, and there are more than 100 peaks corresponding to different organic compounds detected. However, many of them cannot be identified. The major compounds are shown in Table 8 and the area percentage in the tables represents the area fraction under the peak for that identified component. The highest peak areas of the identified compounds were for $n$-hexadecanoic acid, cholest-4-ene, octadecanoic acid, hexadecanamide, oleic acid, 4-methyl phenol, toluene, indole, and so on. Oleic acid is a monounsaturated fatty acid, and can be found in a variety of animal and vegetable materials. The saturated form of this acid is stearic acid, and is used in Lorenzo's oil. Indole is generally used in the production of synthetic jasmine oil. Huang et al. also investigated bio-oil from pyrolysis of granular sewage sludge [49]. In their study, the GC-MS results of bio-oil also indicated $n$-hexadecanoic acid $\left(\mathrm{C}_{16} \mathrm{H}_{32} \mathrm{O}_{2}\right)$ is the major component at the pyrolysis temperature of $500{ }^{\circ} \mathrm{C}$, which is close to our operation condition. The $n$-hexadecanoic acid accounts for a large proportion of the known ingredients in the sludge pyrolytic oil. The other identical components in both studies include octadecanoic acid $\left(\mathrm{C}_{18} \mathrm{H}_{36} \mathrm{O}_{2}\right)$, tetradecanoic acid $\left(\mathrm{C}_{14} \mathrm{H}_{28} \mathrm{O}_{2}\right)$ and hexadecanamide $\left(\mathrm{C}_{16} \mathrm{H}_{33} \mathrm{NO}\right)$. In general, carboxylic acid is the most compound type of the known ingredients.

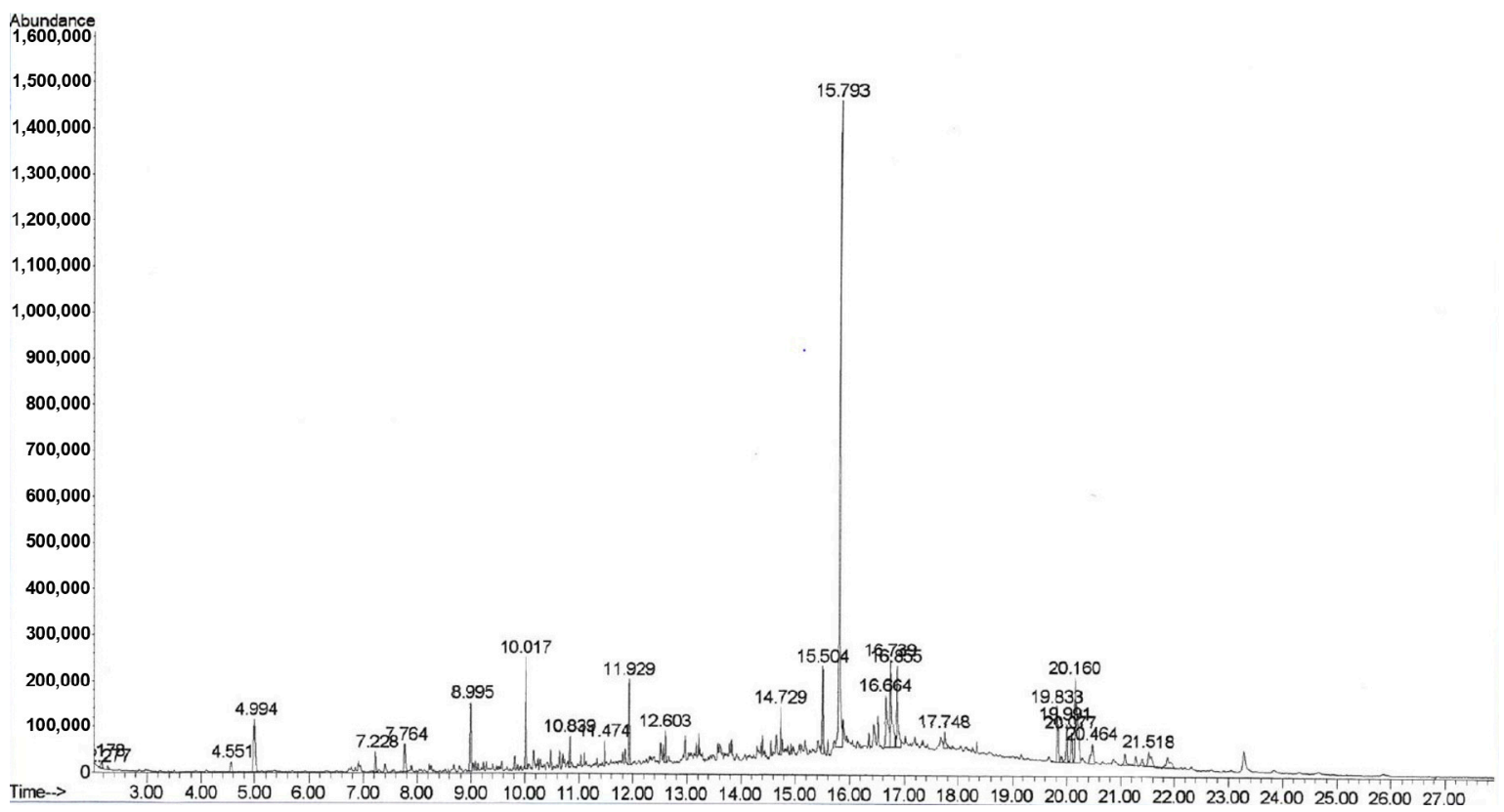

Figure 6. GC-MS mass spectra for sludge pyrolytic oil. 
Table 8. GC-MS analysis of sludge pyrolytic oil.

\begin{tabular}{ccccc}
\hline Peak & Retention Time & Chemical Name & Mol Formula & Area\% \\
\hline 1 & 2.178 & acetic acid & $\mathrm{C}_{2} \mathrm{H}_{4} \mathrm{O}_{2}$ & $0.40 \%$ \\
2 & 2.277 & 2-butanone & $\mathrm{C}_{4} \mathrm{H}_{8} \mathrm{O}$ & $0.18 \%$ \\
3 & 4.551 & Pyrrole & $\mathrm{C}_{4} \mathrm{H}_{5} \mathrm{~N}$ & $0.75 \%$ \\
4 & 4.994 & Toluene & $\mathrm{C}_{7} \mathrm{H}_{8}$ & $3.63 \%$ \\
5 & 7.228 & ethyl benzene & $\mathrm{C}_{8} \mathrm{H}_{10}$ & $0.93 \%$ \\
6 & 7.764 & styrene & $\mathrm{C}_{8} \mathrm{H}_{8}$ & $1.47 \%$ \\
7 & 8.995 & phenol & $\mathrm{C}_{6} \mathrm{H}_{6} \mathrm{O}$ & $3.07 \%$ \\
8 & 10.017 & 4-methyl phenol & $\mathrm{C}_{7} \mathrm{H}_{8} \mathrm{O}$ & $4.41 \%$ \\
9 & 10.839 & 4-ethyl phenol & $\mathrm{C}_{8} \mathrm{H}_{10} \mathrm{O}$ & $1.23 \%$ \\
10 & 11.474 & benzene propane nitrile & - & $0.87 \%$ \\
11 & 11.929 & indole & $\mathrm{C}_{8} \mathrm{H}_{7} \mathrm{~N}$ & $3.18 \%$ \\
12 & 12.603 & 3-methyl indole & $\mathrm{C}_{9} \mathrm{H}_{9} \mathrm{~N}$ & $1.31 \%$ \\
13 & 14.729 & tetradecanoic acid & $\mathrm{C}_{14} \mathrm{H}_{28} \mathrm{O}_{2}$ & $1.83 \%$ \\
14 & 15.504 & pentadecanenitrile & $\mathrm{C}_{15} \mathrm{H}_{29} \mathrm{~N}$ & $3.17 \%$ \\
15 & 15.793 & n-hexadecanoic acid & $\mathrm{C}_{16} \mathrm{H}_{32} \mathrm{O}_{2}$ & $31.90 \%$ \\
16 & 16.664 & oleic acid & $\mathrm{C}_{18} \mathrm{H}_{34} \mathrm{O}_{2}$ & $4.86 \%$ \\
17 & 16.739 & octadecanoic acid & $\mathrm{C}_{18} \mathrm{H}_{36} \mathrm{O}_{2}$ & $5.89 \%$ \\
18 & 16.855 & hexadecanamide & $\mathrm{C}_{16} \mathrm{H}_{33} \mathrm{NO}$ & $4.97 \%$ \\
19 & 17.748 & octadecanamide & $\mathrm{C}_{18} \mathrm{H}_{37} \mathrm{NO}$ & $1.06 \%$ \\
20 & 19.833 & Unknown & & - \\
21 & 19.991 & cholest-2-ene & $\mathrm{C}_{27} \mathrm{H}_{46}$ & $3.18 \%$ \\
22 & 20.077 & cholest-3-ene & $\mathrm{C}_{27} \mathrm{H}_{46}$ & $1.69 \%$ \\
23 & 20.16 & cholest-4-ene & $\mathrm{C}_{27} \mathrm{H}_{46}$ & $9.42 \%$ \\
24 & 20.464 & cholesta-3.5-dienl & - & $2.10 \%$ \\
25 & 21.518 & unknown & - & $6.41 \%$ \\
\hline
\end{tabular}

\subsection{Combustion Characteristic Parameters}

Thermogravimetric analysis was performed for sludge pyrolytic oil (SPO), heavy fuel oil (HFO), $20 \% \mathrm{SPO} / 80 \% \mathrm{HFO}$, and $50 \% \mathrm{SPO} / 50 \% \mathrm{HFO}$, and the results were used to calculate the ignition temperature, burnout temperature, combustion characteristic index (S) and flammability index (C). In these experiments, the samples were inserted into an alumina crucible and heated up to $1200{ }^{\circ} \mathrm{C}$ at the heating rate of $10^{\circ} \mathrm{C} / \mathrm{min}$. A nitrogen flow rate of $50 \mathrm{~mL} / \mathrm{min}$ is used for the pyrolysis process and an air flow rate of $50 \mathrm{~mL} / \mathrm{min}$ is used for the oxidation reaction.

Figure 7 shows the TGA burning profiles of different blending ratio for sludge pyrolytic oil/heavy fuel oil, and the TG pyrolysis curve for sludge pyrolytic oil with $\mathrm{N}_{2}$ carrying gas is also shown to identify the ignition temperature. In Figure 7a, the main reaction for pure sludge pyrolytic oil occurs between 300 and $600{ }^{\circ} \mathrm{C}$. The oxidation processes can be divided into three stages, as follows. (1) The stage of moisture release: the first peak of DTG curves occurs between 30 and $136{ }^{\circ} \mathrm{C}$, corresponding to the endothermic reaction in the DSC curve. This mainly represents the heat adsorption by water and the organic matter with low boiling point. The weight loss in this stage is about $21.63 \mathrm{wt} \%$. (2) The volatilization and oxidation stage of the light volatile substance, which occurs between $136{ }^{\circ} \mathrm{C}$ and $471{ }^{\circ} \mathrm{C}$. The DSC curve indicates an exothermic reaction in this stage, and the weight loss is about $65.21 \mathrm{wt} \%$. (3) The stage of nonvolatile combustion, which represents the combustion of heavy organic matter after $471{ }^{\circ} \mathrm{C}$, and there is a peak in the DTG curve at the temperature of $565{ }^{\circ} \mathrm{C}$, corresponding to a higher exothermic peak in the DSC curve. The weight loss in this stage is about $11.67 \mathrm{wt} \%$. Finally, the remaining substance after oxidation is about $1.16 \mathrm{wt} \%$. 

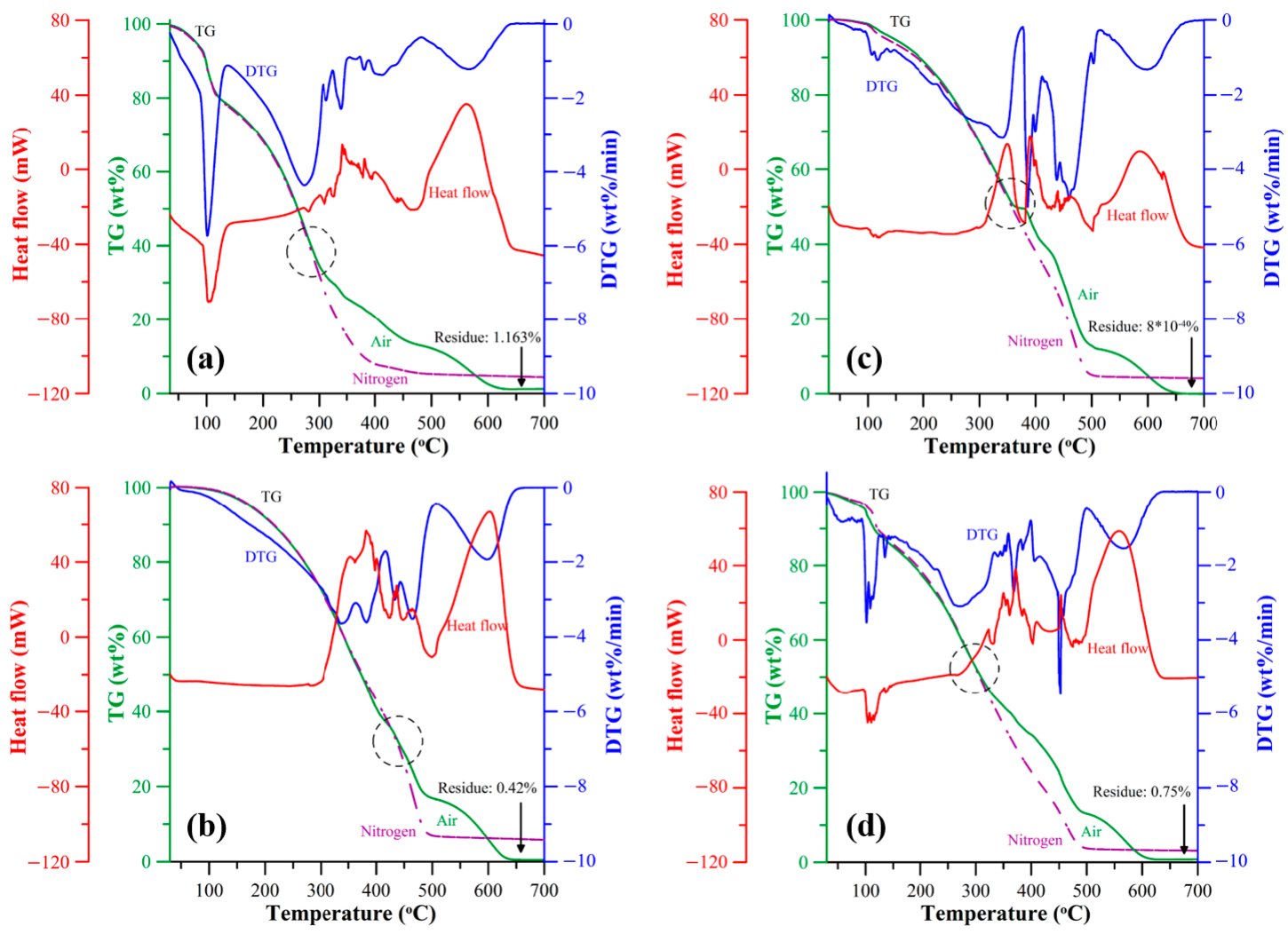

Figure 7. TGA burning profiles of sludge pyrolytic oil at a heating rate of $10{ }^{\circ} \mathrm{C} / \mathrm{min}$ and air flow rate of $50 \mathrm{~mL} / \mathrm{min}$. (a) Pure sludge pyrolytic oil; (b) pure heavy fuel oil; (c) 20\% sludge pyrolytic oil and $80 \%$ heavy fuel oil; (d) 50\% sludge pyrolytic oil and 50\% heavy fuel oil. (Green curve: TG; blue curve: DTG; red curve: DSC; purple curve: TG in the pyrolysis process).

In Figure $7 \mathrm{~b}$, the main reaction for pure heavy fuel oil occurs between 300 and $650{ }^{\circ} \mathrm{C}$. The oxidation processes have two stages, as follows. (1) The volatilization and oxidation stage of light volatile substances and there are several peaks in the DTG curve between 300 and $510{ }^{\circ} \mathrm{C}$. The DSC curve indicates an exothermic reaction in this stage, and the weight loss is about $83.41 \mathrm{wt}$ $\%$. (2) The stage of nonvolatile combustion represents the combustion of heavy organic matter after $510{ }^{\circ} \mathrm{C}$, and there is a peak in the DTG curve at the temperature of about $600{ }^{\circ} \mathrm{C}$, corresponding to a higher exothermic peak in the DSC curve. The weight loss in this stage is about $16.06 \mathrm{wt} \%$. Finally, the remaining residue is about $0.42 \mathrm{wt} \%$.

For the blends, Figure 7c shows the TGA burning profiles of $20 \%$ sludge pyrolytic oil/ $80 \%$ heavy fuel oil. The TG curve decreases faster than that of pure heavy oil due to the mixture of sludge pyrolytic oil, which has more volatile organic compounds. Similar to the case of pure sludge pyrolytic oil, the reaction processes can be divided into three stages, as follows. (1) The stage of moisture release, when the first peak of the DTG curves occurs between 30 and $150{ }^{\circ} \mathrm{C}$ and the weight loss in this stage is about $5.17 \mathrm{wt} \%$. (2) The volatilization and oxidation stage of the light volatile substances, which occurs between 150 and $510{ }^{\circ} \mathrm{C}$; the overall trend is the same as for the heavy oil. The DSC curve indicates an exothermic reaction in this stage, and the weight loss is about $82.97 \mathrm{wt} \%$. (3) The stage of nonvolatile combustion, which represents the combustion of heavy organic matter above $510{ }^{\circ} \mathrm{C}$. There is a peak in the DTG curve at the temperature of about $600^{\circ} \mathrm{C}$, corresponding to a higher exothermic peak in the DSC curve, and the weight loss in this stage is about $11.87 \mathrm{wt} \%$. There is almost no residue left after oxidation.

When the blending ratio increases to $50 \%$ as shown in Figure $7 \mathrm{~d}$, The TG curve only decreases slower than that of pure sludge pyrolytic oil in these cases, and this is primarily due to the mixture of 
sludge pyrolytic oil, which has more volatile organic compounds. The reaction processes can also be divided into three stages, as follows. (1) The stage of moisture release, when the first peak of the DTG curves occurs between 30 and $145^{\circ} \mathrm{C}$, and the weight loss in this stage is about $14.23 \mathrm{wt} \%$. (2) The volatilization and oxidation stage of the light volatile substances, which occurs between 145 and $500{ }^{\circ} \mathrm{C}$ and can be further divided into two parts. The first is close to the oxidation of sludge pyrolytic oil and is between 145 and $415^{\circ} \mathrm{C}$, while the second is close to the oxidation of heavy fuel oil and is between 415 and $500{ }^{\circ} \mathrm{C}$. The DSC curve indicates an exothermic reaction in this stage, and the weight loss is about $72.58 \mathrm{wt} \%$. (3) The stage of nonvolatile combustion, which represents the combustion of heavy organic matter above $500{ }^{\circ} \mathrm{C}$. There is a peak in the DTG curve at the temperature of $566{ }^{\circ} \mathrm{C}$, corresponding to a higher exothermic peak in the DSC curve, and the weight loss in this stage is about $12.3 \mathrm{wt} \%$. After oxidation, the residue is about $0.75 \mathrm{wt} \%$.

From Figure 7, these results show that for the blends the second DTG peak, which represents the combustion of volatile substances and determines the ignition temperature, shifts to a lower temperature when compared to the case of pure heavy fuel oil. As can be seen in the TGs and DTGs for the blends of sludge pyrolytic oil and heavy fuel oil, there is an obvious interaction between the blend components. Table 9 shows the combustion characteristic parameters of sludge pyrolytic oil, heavy fuel oil, and the blends. Sludge pyrolytic oil has a lower ignition temperature $\left(274{ }^{\circ} \mathrm{C}\right)$ than heavy fuel oil $\left(434^{\circ} \mathrm{C}\right)$, since it has more volatile matter. In addition, a greater percentage of sludge pyrolytic oil in the blend will reduce the ignition temperature to a greater extent. We also found similar trends for combustion characteristics of a single droplet in the suspended droplet experimental system [50]. A higher blending ratio of sludge pyrolytic oil will make ignition easier. However, the burnout temperature is around $600{ }^{\circ} \mathrm{C}$ in all these cases because the combustion characteristics of heavy organic matter (the last DTG peak) are similar for these oils. The last DTG peak derived from the oxidation of heavy organic matter determines the burnout temperature. Table 9 also shows that the maximum combustion rate of sludge pyrolytic oil is higher than that of heavy fuel oil. An interesting finding is that the maximum combustion rate in the blend is even higher than for pure sludge pyrolytic oil. This indicates that there is an interaction between these blend components, and synergistic effects can be perceived. In addition, as the blending ratio of sludge pyrolytic oil increases, the maximum combustion rate also moves to a lower temperature and represents the domination shifts from heavy organic matter to light volatile substances. Finally, the flammability index and combustion characteristics index in the blend are higher than those of heavy fuel oil. Since the sludge pyrolytic oil has a higher volatile content than heavy fuel oil, adding a certain amount of sludge pyrolytic oil will promote the ignition performance of heavy fuel oil, which is conductive to the stability of heavy fuel oil combustion. The co-combustion of sludge pyrolytic oil and heavy fuel oil has better combustion characteristics than seen with pure heavy fuel oil. Moreover, it is even better than pure sludge pyrolytic oil, especially in the case of $50 \%$ sludge pyrolytic oil mixed with $50 \%$ heavy fuel oil.

Table 9. The combustion characteristic parameters of sludge pyrolytic oil, heavy fuel oil, and the blends.

\begin{tabular}{ccccccc}
\hline Fuel & $(\boldsymbol{d W} / \boldsymbol{d} \tau)_{\max }$ & $(\boldsymbol{d W} / \boldsymbol{d} \tau)_{\text {mean }}$ & $\boldsymbol{T}_{\boldsymbol{i}}\left({ }^{\circ} \mathbf{C}\right)$ & $\boldsymbol{T}_{\boldsymbol{e}}\left({ }^{\circ} \mathbf{C}\right)$ & $S \times 10^{7}$ & $\boldsymbol{C} \times 10^{5}$ \\
\hline Heavy fuel oil & 3.517 & 1.544 & 434 & 612 & 0.470 & 1.863 \\
20\%SPO + 80\%HFO & 5.003 & 1.783 & 311 & 601 & 1.531 & 5.157 \\
$50 \%$ SPO + 50\%HFO & 5.464 & 1.562 & 295 & 600 & 1.631 & 6.257 \\
Sludge pyrolytic oil & 4.360 & 1.162 & 274 & 605 & 1.114 & 5.832 \\
\hline
\end{tabular}

\section{Conclusions}

The Taguchi method was used in this study to optimize the pyrolysis of sewage sludge for obtaining the maximum pyrolytic oil yield. The combustion characteristic parameters are evaluated based on a thermogravimetric analysis to explore the combustion characteristics of sludge pyrolytic oil and heavy fuel oil. The findings of this study are summarized as follows. 
(1) The effective sequence of pyrolytic parameters for the yield of sludge pyrolytic oil is nitrogen flow rate, pyrolytic temperature, heating rate, and residence time. The best operating conditions for sewage sludge pyrolysis are a heating rate of $10^{\circ} \mathrm{C} / \mathrm{min}$, pyrolysis temperature of $450{ }^{\circ} \mathrm{C}$, residence time of $60 \mathrm{~min}$, and nitrogen flow rate of $700 \mathrm{~mL} / \mathrm{min}$. Under these conditions, the obtained pyrolytic oil yield is $10.19 \%$ (18.4\% on dry ash free (daf) basis), which is very close to $10.44 \%$ (18.85\% on dry ash free (daf) basis.), the ideal value from the Taguchi method.

(2) From the thermogravimetric analysis of sludge pyrolytic oil, the combustion performance parameters, such as the ignition temperature, burnout temperature, flammability index, and combustion characteristics index, are calculated and compared with those of heavy fuel oil. Since the sludge pyrolytic oil has volatile substances with lower boiling temperatures, it has a lower ignition temperature and better combustion characteristics than heavy fuel oil.

(3) For the blends of sludge pyrolytic oil and heavy fuel oil, the maximum combustion rate, the flammability index, and combustion characteristics index all increase markedly along with the amount of sludge pyrolytic oil. Sludge pyrolytic oil significantly enhances the combustion of heavy fuel oil, with the mix producing even better results than those seen with pure sludge pyrolytic oil (synergistic effects).

Author Contributions: G.-B.C. and Y.-C.C. contributed to the concept, results explanation and writing of the paper. J.-W.L. performed the experiments and analyzed the data. H.-T.L. and F.-H.W. contributed to experimental method and paper review.

Funding: This research was funded by the Ministry of Science and Technology of Republic of China grant number MOST 104-ET-E-006-001-ET.

Conflicts of Interest: The authors declare no conflict of interest.

\section{References}

1. Chen, G.B.; Li, Y.H.; Cheng, T.S.; Chao, Y.C. Chemical effect of hydrogen peroxide addition on characteristics of methane-air combustion. Energy 2013, 55, 564-570. [CrossRef]

2. Starikovskiy, A.; Aleksandrov, N. Plasma-assisted ignition and combustion. Prog. Energy Combust. Sci. 2013, 39, 61-110. [CrossRef]

3. Kaminski, W.; Marszalek, J.; Ciolkowska, A. Renewable energy source-dehydrated ethanol. Chem. Eng. J. 2008, 13, 95-102. [CrossRef]

4. Nigam, P.S.; Singh, A. Production of liquid biofuels from renewable resources. Porg. Energy Combust. Sci. 2011, 37, 52-68. [CrossRef]

5. Werther, J.; Ogada, T. Sewage sludge combustion. Prog. Energy Combust. Sci. 1999, 25, 55-116. [CrossRef]

6. Cantrell, K.B.; Ducey, T.; Ro, K.S.; Hunt, P.G. Livestock waste-to-bioenergy generation opportunities. Bioresour. Technol. 2008, 99, 7941-7953. [CrossRef] [PubMed]

7. Hossain, F.M.; Kosinkova, J.; Brown, R.J.; Ristovski, Z.; Hankamer, B.; Stephens, E.; Rainey, T.J. Experimental investigations of physical and chemical properties for microalgae HTL bio-crude using a large batch reactor. Energies 2017, 10, 467. [CrossRef]

8. Kim, K.H.; Lee, E.Y. Environmentally-Benign Dimethyl Carbonate-Mediated Production of Chemicals and Biofuels from Renewable Bio-Oil. Energies 2017, 10, 1790. [CrossRef]

9. Rowhani, A.; Rainey, T.J. Scrap tyre management pathways and their use as a fuel-A review. Energies 2016, 9, 888. [CrossRef]

10. Karagoz, S.; Bhaskar, T.; Muto, A.; Sakata, Y.; Oshiki, T.; Kishimoto, T. Low-temperature catalytic hydrothermal treatment of wood biomass: Analysis of liquid products. Chem. Eng. J. 2005, 108, 127-137. [CrossRef]

11. Asadullah, M.; Rahman, M.A.; Ali, M.M.; Motin, M.A.; Sultan, M.B.; Alam, M.R. Production of bio-oil from fixed bed pyrolysis of bagasse. Fuel 2007, 86, 2514-2520. [CrossRef]

12. Ferreira, L.C.; Nilsen, P.J.; Fdz-Polanco, F.; Perez-Elvira, S.I. Biomethane potential of wheat straw: Influence of particle size, water impregnation and thermal hydrolysis. Chem. Eng. J. 2014, 242, 254-259. [CrossRef] 
13. Lewandowski, I.; Clifton-Brown, J.C.; Scurlock, J.M.O.; Huisman, W. Miscanthus: European experience with a novel energy crop. Biomass Bioenergy 2000, 19, 209-227. [CrossRef]

14. Chen, G.L.; Chen, G.B.; Li, Y.H.; Wu, W.T. A study of thermal pyrolysis for castor meal using the Taguchi method. Energy 2014, 71, 62-70. [CrossRef]

15. Chen, W.H.; Lin, B.J. Characteristics of products from the pyrolysis of oil palm fiber and its pellets in nitrogen and carbon dioxide atmospheres. Energy 2016, 94, 569-578. [CrossRef]

16. Lam, S.S.; Liew, R.K.; Lim, X.Y.; Ani, F.N.; Jusoh, A. Fruit waste as feedstock for recovery by pyrolysis technique. Int. Biodeterior. Biodegrad. 2016, 113, 325-333. [CrossRef]

17. Islam, M.N.; Beg, M.R.A.; Islam, M.R. Pyrolytic oil from fixed bed pyrolysis of municipal solid waste and its characterization. Renew. Energy 2005, 30, 413-420. [CrossRef]

18. Lam, S.S.; Liew, R.K.; Jusoh, A.; Chong, C.T.; Ani, F.N.; Chase, H.A. Progress in waste oil to sustainable energy, with emphasis on pyrolysis techniques. Renew. Sustain. Energy Rev. 2016, 53, 741-753. [CrossRef]

19. Mohan, D.; Pittman, C.U.; Steele, P.H. Pyrolysis of wood/biomass for bio-oil: A critical review. Energy Fuels 2006, 208, 48-89. [CrossRef]

20. Basu, P. Biomass Gasification, Pyrolysis and Torrefaction Practial Design and Theory, 2nd ed.; Academic Press: Cambridge, MA, USA, 2013.

21. Fonts, I.; Gea, G.; Azuar, M.; Ábrego, J.; Arauzo, J. Sewage sludge pyrolysis for liquid production: A review. Renew. Sustain. Energy Rev. 2012, 16, 2781-2805. [CrossRef]

22. Inguanzo, M.; Domínguez, A.; Menéndez, J.A.; Blanco, C.G.; Pis, J.J. On the pyrolysis of sewage sludge: The influence of pyrolysis conditions on solid, liquid and gas fractions. J. Anal. Appl. Pyrolysis 2002, 63, $209-222$. [CrossRef]

23. Kim, Y.; Parker, W. A technical and economic evaluation of the pyrolysis of sewage sludge for the production of bio-oil. Bioresour. Technol. 2008, 99, 1409-1416. [CrossRef] [PubMed]

24. Domínguez, A.; Menéndez, J.A.; Inguanzo, M.; Bernad, P.L.; Pis, J.J. Gas chromatographic-mass spectrometric study of the oil fractions produced by microwave-assisted pyrolysis of different sewage sludges. J. Chromatogr. A 2003, 1012, 193-206. [CrossRef]

25. Domínguez, A.; Menéndez, J.A.; Inguanzo, M.; Pis, J.J. Investigations into the characteristics of oils produced from microwave pyrolysis of sewage sludge. Fuel Process Technol. 2005, 86, 1007-1020. [CrossRef]

26. Domínguez, A.; Menéndez, J.A.; Inguanzo, M.; Pis, J.J. Production of bio-fuels by high temperature pyrolysis of sewage sludge using conventional and microwave heating. Bioresour. Technol. 2006, 97, 1185-1193. [CrossRef] [PubMed]

27. Sánchez, M.E.; Menéndez, J.A.; Domínguez, A.; Pis, J.J.; Martínez, O.; Calvo, L.F.; Bernad, P.L. Effect of pyrolysis temperature on the composition of the oils obtained from sewage sludge. Biomass Bioenergy 2009, 33, 933-940. [CrossRef]

28. Jeguirim, M.; Dutournié, P.; Zorpas, A.A.; Limousy, L. Olive mill wastewater: From a pollutant to green fuels, agricultural water source and bio-fertilizer-Part 1. The drying kinetics. Energies 2017, 10, 1423. [CrossRef]

29. Azuara, M.; Ábrego, J.; Fonts, I.; Gea, G.; Murillo, M.B. Ammonia Content of Bottom Phase Liquid from Pyrolyisis of Sewage Sludge in a Bubbling Fluidized Bed. In Proceedings of the 18th European Biomass Conference and Exhibition, Lyon, France, 3-7 May 2010.

30. Cao, J.P.; Zhao, X.Y.; Morishita, K.; Li, L.Y.; Xiao, X.B.; Obara, R.; Wei, X.Y.; Takarada, T. Triacetonamine formation in a bio-oil from fast pyrolysis of sewage sludge using acetone as the absorption solvent. Bioresour. Technol. 2010, 101, 4242-4245. [CrossRef] [PubMed]

31. Tang, B. Orthogonal array-based hypercube. J. Am. Statist. Assoc. 1993, 88, 1392-1397. [CrossRef]

32. Yang, W.H.; Tarng, Y.S. Design optimization of cutting parameters for turning operations based on the Taguchi method. J. Mater. Process. Technol. 1998, 84, 122-129. [CrossRef]

33. Ghani, J.A.; Choudhury, I.A.; Hassan, H.H. Application of Taguchi method in the optimization of end milling parameters. J. Mater. Process. Technol. 2004, 145, 84-92. [CrossRef]

34. Tognotti, L.; Malotti, A.; Petarca, L.; Zanelli, S. Measurement of ignition temperature of coal particles using a thermogravimetric technique. Combust. Sci. Technol. 1985, 15, 15-28. [CrossRef]

35. Crelling, J.C.; Hippo, E.J.; Woerner, B.A.; West, D.P., Jr. Combustion characteristics of selected whole coals and macerals. Fuel 1992, 71, 151-158. [CrossRef]

36. Huang, X.; Jiang, X.; Han, X.; Wang, H. Combustion characteristics of fine- and micro-pulverizes coal in the misture of $\mathrm{O}_{2} / \mathrm{CO}_{2}$. Energy Fuels 2008, 22, 3756-3762. [CrossRef] 
37. Wall, T.F.; Gupta, R.P.; Gururajan, V.S.; Zhang, D. The ignition of coal particles. Fuel 1991, 70, $1011-1016$. [CrossRef]

38. Jin, Y.; Li, Y.; Liu, F. Combustion effects and emission characteristics of $\mathrm{SO}_{2}, \mathrm{CO}, \mathrm{NO}_{\mathrm{x}}$ and heavy metals during co-combustion of coal and dewatered sludge. Front. Environ. Sci. Eng. 2015, 10, 201-210. [CrossRef]

39. Cheng, J.Y.; Sun, X.X. Determination of the devolatilization index and combustion characteristic index of pulverized coals. Power Eng. 1987, 7, 13-18.

40. Wang, Y.; Chen, G.; Li, Y.; Yan, B.; Pan, D. Experimental study of the bio-oil production from sewage sludge by supercritical conversion process. Waste Manag. 2013, 33, 2408-2415. [CrossRef] [PubMed]

41. Thipkhunthod, P.; Meeyoo, V.; Rangsunvigit, P.; Kitiyanan, B.; Siemanond, K.; Rirksomboon, T. Pyrolytic characteristics of sewage sludge. Chemosphere 2006, 64, 955-962. [CrossRef] [PubMed]

42. Gómez-Rico, M.F.; Font, R.; Fullana, A.; Martín-Gullón, I. Thermogravimetric study of different sewage sludges and their relationship with the nitrogen content. J. Anal. Appl. Pyrolysis 2005, 74, 421-428. [CrossRef]

43. Kristensen, E. Characterization of biogenic organic natter by stepwise thermogravimetry (STG). Biogeochemistry 1990, 9, 135-139. [CrossRef]

44. Li, J.J.; Qi, B.Y.; Li, A.M.; Duan, Y.; Wang, Z. Thermal analysis and products distribution of dried sewage sludge pyrolysis. J. Anal. Appl. Pyrolysis 2014, 105, 43-48.

45. Pütün, E. Catalytic pyrolysis of biomass: Effects of pyrolysis temperature, sweeping gas flow rate and $\mathrm{MgO}$ catalyst. Energy 2010, 35, 2761-2766.

46. Chen, W.H.; Chen, C.J.; Hung, C.I. Taguchi approach for co-gasification optimization of torrefied biomass and coal. Bioresour. Technol. 2013, 144, 615-622. [CrossRef] [PubMed]

47. Das, S.P.; Gupta, A.; Das, D.; Goyal, A. Enhanced bioethanol production from water hyacinth (Eichhornia crassipes) by statistical optimization of fermentation process parameters using Taguchi orthogonal array design. Int. Biodeterior. Biodegrad. 2016, 109, 174-184. [CrossRef]

48. Pattanaik, A.; Satpathy, M.P.; Mishra, S.C. Dry sliding wear behavior of epoxy fly ash composite with Taguchi optimization. Eng. Sci. Technol. Int. J. 2016, 19, 710-716. [CrossRef]

49. Huang, F.; Yu, Y.; Huang, H. Temperature influence and distribution of bio-oil from pyrolysis of granular sewage sludge. J. Anal. Appl. Pyrolysis 2018, 130, 36-42. [CrossRef]

50. Li, J.W. A Study of Thermal Process for Sewage Sludge Pyrolytic Oil and its Combustion Characteristics. Master's Thesis, National Cheng Kung University, Tainan, Taiwan, 2016. 